6. Хранение картофеля / К. А. Пшеченков, В. Н. Зейрук, С.Н. Еланский [и др.]. - Москва: Агроспас, 2016. - 144 с. - Текст: непосредственный.

7. Доспехов, Б. А. Методика полевого опыта с основами статистической обработки результатов исследований / Б. А. Доспехов. - 6-е изд., стер. - Москва: Альянс, 2011. - 351 с. - Текст: непосредственный.

8. Baranowska, A. (2019). Influence of Pluviothermal conditions, growth biostimulators and herbicide on dry matter content and starch in edible potato tubers. Applied Ecology and Environmental Research. $17 . \quad$ 1547-1557. DOI: 10.15666/aeer/1702_15471557.

9. Kondratenko, E.P., Izhmulkina, E.A., Miroshina, T.A. Sartakova, O.A. Competitiveness of Potato Varieties in the South-East of Western Siberia Market // XIX International Scientific and Practical Conference "Current Trends of Agricultural Industry in Global Economy". DOI: https://doi.org/10.32743/agri.gl.econ.2020.133-144.

\section{References}

1. Liu, S., et al. (2019). Quality Changes of Different Varieties of Fresh-Type Potatoes during Storage. IOP Conference Series: Materials Science and Engineering. DOI:10.1088/1757899X/562/1/012123.

2. Voronov, E., et al. (2019). Formation of yield and commodity qualities of potatoes, depending on the varietal characteristics. IOP Conference Series: Earth and Environmental Science. 346. 012028. DOI: 10.1088/1755-1315/346/1/012028.
3. Kondratenko E. P. Sort kak faktor povysheniia urozhainosti i kachestva kartofelia $\mathrm{V}$ usloviiakh stepnoi zony iuga-vostoka Zapadnoi Sibiri / E. P. Kondratenko, O. B. Konstantinova, T. A. Miroshina, O. M. Soboleva // Dostizheniia nauki i tekhniki APK. - 2020. - T. 34. - No. 12. S. 56-60. - DOI 10.24411/0235-2451-2020-11209.

4. Balendres, M., Tegg, R., Wilson, C. (2016). Key events in pathogenesis of spongospora diseases in potato: a review. Australasian Plant Pathology. 45. DOI: 10.1007/s13313-016-0398-3.

5. Buttimer C., McAuliffe O., Ross R.P., et al. (2017) Bacteriophages and Bacterial Plant Diseases. Front. Microbiol. 8:34. DOI: 10.3389/fmicb.2017.00034.

6. Khranenie kartofelia / K. A. Pshechenkov, V. N. Zeiruk, S.N. Elanskii, S.V. Maltsev, S.B. Priamov. - Moskva: Agrospas, 2016. - 144 s.

7. Dospekhov, B.A. Metodika polevogo opyta s osnovami statisticheskoi obrabotki rezultatov issledovanii / B.A. Dospekhov. - Izd. 6-e, ster. Moskva: Alians, 2011. - $351 \mathrm{~s}$.

8. Baranowska, A. (2019). Influence of Pluviothermal conditions, growth biostimulators and herbicide on dry matter content and starch in edible potato tubers. Applied Ecology and Environmental Research. $17 . \quad 1547-1557 . \quad$ DOI: 10.15666/aeer/1702_15471557.

9. Kondratenko, E.P., Izhmulkina, E.A., Miroshina, T.A. Sartakova, O.A. Competitiveness of Potato Varieties in the South-East of Western Siberia Market // XIX International Scientific and Practical Conference "Current Trends of Agricultural Industry in Global Economy". DOI: https://doi.org/10.32743/agri.gl.econ.2020.133-144. ПРИ ПРЕДПОСЕВНОЙ ОБРАБОТКЕ СЕМЯН БИОЛОГИЧЕСКИМИ ПРЕПАРАТАМИ

\title{
BARLEY YIELDING CAPACITY INDICES BY PRE-SOWING SEED TREATMENT WITH BIOLOGICAL PREPARATIONS
}

Ключевые слова: ячмень, биологические препараты, полова овса, хвоя сосны, семена, урожайность, вариабельность, фрактор масса 1000 зерен, зерно, колос.
Keywords: barley, biological preparations, oat chaff, pine needles, seeds, yielding capacity, variability, thousand-kernel weight factor, grain, ear. 
Использование в производственном процессе выращивания сельскохозяйственной продукции высококачественного посевного материала - это один из основных критериев получения хорошего урожая. Цель проведения исследования - изучение влияния предпосевной обработки семян биологическими препаратами на формирование урожайности ячменя в условиях Приобья Алтайского края. Исследовательская работа была проведена в 2019-2020 гг. в условиях Приобской зоны Алтайского края. Объект исследования - сорт ячменя Ворсинский. Предмет исследования - биологические препараты, используемые для предпосевной обработки семян. В опыте было заложено 10 вариантов, из них 4 варианта с использованием биологических препаратов, полученных на основе обработки отходов сельхозпроизводства, деревообработки и верхового торфа методом взрывного автогидролиза. Контроль - обработка дистиллированной водой. Полученные результаты показали, что использование биологических препаратов при возделывании ячменя положительно влияет на конечный результат - урожайность культуры. Средние результаты за два года испытаний показали широкий диапазон варьирования урожайности по вариантам опыта. Показатель урожайности изменялся от 2,15 т/га на варианте 8 до 2,82 т/га на варианте № 5, контроль 2,60 т/га. Величина урожайности на варианте 5 с использованием препарата на основе ВТ - максимальная в опыте. В среднем за два года исследований вариабельность по вариантам была отмечена от средней $10 \%<$ Cv < 20\% на вариантах 2-7 до высокой Cv > 20\% - варианты 6-10. Максимальное положительное влияние на формирование урожайности ячменя сорта Ворсинский оказывает предпосевная обработка семян препаратами, полученными на основе растительных остатков (лузга подсолнечника, полова овса - вариан-

Жаркова Сталина Владимировна, д.с.-Х.Н., доцент, ФГБОУ ВО Алтайский ГАУ, г. Барнаул, Российская Федерация, e-mail: stalina_zharkova@mail.ru.

Киян Наталья Геннадьевна, аспирант, ФГБОУ ВО Алтайский ГАУ, г. Барнаул, Российская Федерация, e-mail: dushkafunny2@gmail.com.

\section{Введение}

Использование в производственном процессе выращивания сельскохозяйственной продукции высококачественного посевного материала - это один из основных критериев получения хорошего урожая. Получению кондиционного семенного материала в настоящее время уделяют большое внимание все подразделения, участвующие в выполнении Указа Президента РФ № 642 от 1 декабря 2016 г. Представленная в Указе Стратегия научно-технологического развития Российской Федерации говорит о переходе к высокопродуктивному и экологически чистому агро- и аквахозяйству, разработке и внед- ты 3, 4), отходов деревообработки (хвоя сосны, вариант 2) и верхового торфа (вариант 5) путём их обработки методом взрывного автогидролиза.

The use of high-quality seeds in the production process of crop growing is one of the main criteria for obtaining a good harvest. The research goal is to study the effect of pre-sowing seed treatment with biological preparations on barley yield formation under the conditions of the Altai Region's Ob River area. The research was carried out in 2019 and 2020 in the Altai Region's Ob River area. The research target was the Vorsinskiy barley variety and the biological preparations used for pre-sowing seed treatment. The experiment included 10 variants; of those 4 variants using biological preparations obtained based on processed agricultural and woodworking wastes, and top peat processed by autohydrolysis-explosion. The control consisted in seed treatment with distilled water. The results obtained showed that the use of biological preparations in barley cultivation had a positive effect on the final result - crop yield. The average results over two years of testing showed a wide range of yield variations in the experiment variants. The yield values varied from 2.15 t ha in the Variant no. 8 to $2.82 \mathrm{t}$ ha in the Variant no. 5; the control $-2.60 \mathrm{t}$ ha. The yield value in the Variant no. 5 with the use of top peat preparation was the maximum in the experiment. On average, over two years of research, the variability in the variants was from the medium of $10 \%<\mathrm{Cv}<20 \%$ in the Variants no. 2, 3, 4, 5, 7 to high $\mathrm{Cv}>20 \%$ - Variants no. 6, 8, 9, 10. The maximum positive effect on the yield formation of the Vorsinskiy barley variety is exerted by pre-sowing seed treatment with the preparations based of plant residues (sunflower husk, oat chaff - Variants no. 3, 4), woodworking wastes (pine needles - Variant no. 2) and top peat (Variant no. 5) processed by autohydrolysis explosion.

Zharkova Stalina Vladimirovna, Dr. Agr. Sci., Prof., Altai State Agricultural University, Barnaul, Russian Federation, e-mail: stalina_zharkova@mail.ru.

Kiyan Natalya Gennadyevna, post-graduate student, Altai State Agricultural University, Barnaul, Russian Federation, e-mail: dushkafunny2@gmail.com.

рению систем рационального применения средств химической и биологической защиты сельскохозяйственных растений и животных, хранению и эффективной переработке сельскохозяйственной продукции, созданию безопасных и качественных, в том числе функциональных, продуктов питания [1, 2].

Площади, занимаемые ячменём в Российской Федерации, в среднем составляют около 9 млн га. Большая часть посевов, около 75-77\% от всех объёмов, производится в европейской части России. Ячмень в Сибирском регионе относят к одной из важнейших зернофуражных культур. Площади, занимаемые ячменём в Си- 
бирском ФО в 2019 г., составили 1184,0 тыс. га, или $13,5 \%$ от общей площади под культурой в стране. Почвенно-климатические условия Алтайского края дают возможность аграриям успешно выращивать культуру независимо от зоны возделывания. В крае семенами культуры засевается 250-280 тыс. га. Ежегодно Алтайские сельхозпроизводители получают 450-470 тыс. т зерна ячменя, средняя урожайность составляет 1,7-1,8 т/га [3, 4].

Задача производственников при выращивании ячменя - увеличение производства зерна с высокими показателями качества, с наименьшими затратами. Для решения этой проблемы в имеющиеся технологии внедряются новые эффективные элементы, помогающие растениям в условиях возделывания более эффективно использовать свой биологический потенциал, абиотические и биотические факторы среды. К таким элементам следует отнести использование в агротехнологиях биологических препаратов в качестве стимуляторов, регуляторов роста растений и как средство их защиты от болезней и вредителей $[4,5]$.

Цель исследования - изучение влияния предпосевной обработки семян биологическими препаратами на формирование урожайности ячменя в условиях Приобья Алтайского края.

\section{Условия, объекты и методы исследования}

Исследовательская работа была проведена в 2019-2020 гг. в условиях Приобской зоны Алтайского края. Опытный участок был разбит на территории Барнаульского луго-пастбищного участка, филиал ФГБУ «Госсорткомиссия» по Алтайскому краю. Данные анализа почвы опытного участка показали, что они относятся к обыкновенным среднесуглинистым и слабо выщелоченным черноземам.

Погодные условия лет исследования различались. Первая половина вегетационного периода 2019 г. отличалась достаточным количеством осадков. Во второй половине количество осадков снизилось, отмечали засушливые явления. В 2020 г. в первой половине вегетации осадки были редкие и незначительные, что отрицательно сказалось на развитии растений.

Объект исследования - сорт ячменя Ворсинский. Исходная форма получена в результате двукратной обработки сорта Жодинский 5 (К-27372, Беларусь) гамма-лучами в дозе 3,5 кP в 1997-1998 гг. и индивидуального отбора элит- ного растения в 1999 г. Разновидность nutans. Сорт Ворсинский относится к среднеспелой группе. В 2005 г. сорт передан в Госсортоиспытание и в 2011 г. районирован.

Предмет исследования - биологические препараты, используемые для предпосевной обработки семян.

Вариантов в опыте было 10. Из них вариант 1 - контроль. Семена обрабатывали дистиллированной водой; варианты 2-5 - это препараты, полученные обработкой методом взрывного автогидролиза (ВАГ) хвои сосны (отход деревообработки, вариант 2, ХС), отходов сельхозпроизводства - лузги подсолнечника (вариант 3 , ЛП) и половы овса (вариант 4, ПО), верхового торфа (вариант 5, ВТ), варианты: 6 - ТелураБио; 7 Гумат+7; 8 - Цитогумат; 9 - Лигногумат; 10 Ризоплан.

Перед посевом в лаборатории кафедры общего земледелия, расениводства и защиты растений на препаратах, полученных методом ВАГ, была определена концентрация, которая оказывает наибольшую эффективность при прорастании семян. Закладка полевого опыта была проведена на основе методических рекомендаций $[6,7]$ (рис. 1). Предшественник - чистый пар. Норма высева семян - 5 млн всхожих семян на 1 га. Учётная площадь делянки 10 м², повторность четырёхкратная, размещение делянок систематическое. Препаратами обрабатывали семена перед посевом.

\section{Результаты исследования}

Полученные показатели различия по вариантам и по годам проведения исследования представлены в таблице.

Величина урожайности в 2019 г. сформировалась по всем вариантам выше, чем в 2020 г. Отрицательно повлияло на развитие растений в 2020 г. отсуствие осадков или их недостаточное количество.

В среднем урожайность в 2019 г. (2,8 т/га) сформировалась на 27,5\% выше показателя 2020 г. (2,03 т/га). Величина урожайности по вариантам опыта варьировала от 2,55 т/га на варианте 9 с обработкой препаратом Лигногумат до 3,17 т/га - вариант 5 (обработка ВТ методом ВАГ). Максимальное превышение контроля (2,92 т/га) на 0,25 т/га отмечено на вариантах 5 (обработка препаратом из ВТ) и 6 (обработка ТелураБио), соответственно, было получено 3,17 и 3,10 т/га. Полученные показатели на дан- 
ных вариантах достоверны на уровне урожайности стандарта.

Засушливые условия 2020 г. отрицательно повлияли на формирование продуктивности растений и величину урожайности на всех вариантах опыта. Максимальное понижение урожайности на 40-43\% относительно 2019 г. было отмечено на вариантах 6, 10 и 8. Хорошие показа- тели урожайности были получены на вариантах с обработкой семян препаратами с использованием метода ВАГ. Наивысшая урожайность в данном году сформировалась на варианте 3 (2,52 т/га) с предпосевной обработкой семян препаратом, полученным методом ВАГ из лузги подсолнечника, на контроле данный показатель равен 2,28 т/га.

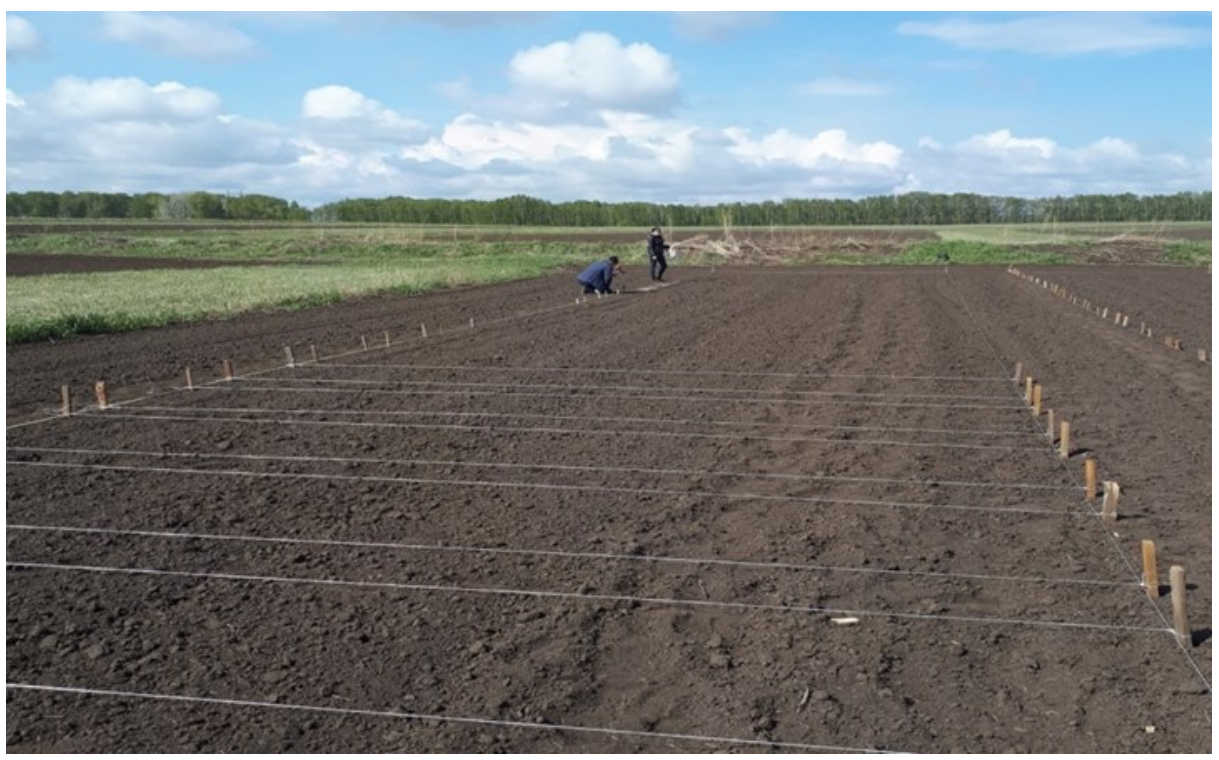

Рис. 1. Закладка опытных делянок

Таблица

Урожайность ячменя в зависимости от предпосевной обработки семян и года исследования, 2019-2020 ट2.

\begin{tabular}{|c|c|c|c|c|c|c|c|c|c|c|c|}
\hline \multirow{2}{*}{\multicolumn{2}{|c|}{ Вариант ${ }^{*}$}} & \multicolumn{10}{|c|}{ Урожайность, т/га } \\
\hline & & 2019 г. & $\pm \mathrm{kst}$. & $\mathrm{Cv}, \%$ & 2020 г. & \% к 2019 г. & $\pm \kappa$ st. & Cv, \% & $\begin{array}{r}2019- \\
2020 \text { гг. }\end{array}$ & \pm k st. & $\mathrm{Cv}, \%$ \\
\hline 1 & Контроль, & 2,92 & - & 1,9 & 2,28 & 78,1 & - & 12,0 & 2,60 & - & 14,7 \\
\hline 2 & $X C^{*}$ & 2,61 & $-0,31$ & 2,5 & 1,97 & 75,5 & $-0,31$ & 15,2 & 2,29 & $-0,31$ & 17,2 \\
\hline 3 & תח* & 2,96 & $+0,04$ & 7,6 & 2,52 & 85,1 & $+0,24$ & 1,9 & 2,74 & $+0,14$ & 10,2 \\
\hline 4 & ПО* & 2,73 & $-0,19$ & 7,7 & 1,98 & 72,5 & $-0,30$ & 6,4 & 2,24 & $-0,36$ & 18,3 \\
\hline 5 & $\mathrm{BT}^{*}$ & 3,17 & $+0,25$ & 2,9 & 2,48 & 78,2 & $+0,20$ & 9,9 & 2,82 & $+0,22$ & 14,5 \\
\hline 6 & ТелураБио & 3,10 & $+0,25$ & 7,8 & 1,77 & 57,1 & $-0,51$ & 15,3 & 2,43 & $-0,17$ & 30,8 \\
\hline 7 & Гумат +7 & 2,61 & $-0,31$ & 8,0 & 2,06 & 78,9 & $-0,22$ & 23,3 & 2,33 & $-0,27$ & 14,4 \\
\hline 8 & Цитогумат & 2,59 & $-0,33$ & 7,8 & 1,71 & 66,0 & $-0,57$ & 12,0 & 2,15 & $-0,45$ & 23,6 \\
\hline 9 & Лигногумат & 2,55 & $-0,37$ & 10,9 & 1,81 & 71,0 & $-0,47$ & 13,8 & 2,18 & $-0,42$ & 21,4 \\
\hline 10 & Ризоплан & 2,91 & $-0,01$ & 3,4 & 1,76 & 60,5 & $-0,52$ & 8,8 & 2,33 & $-0,27$ & 26,8 \\
\hline & Средняя & 2,80 & - & - & 2,03 & & - & - & 2,41 & - & - \\
\hline & $\mathrm{HCP}_{0,5}, \mathrm{~T} /$ га & 0,26 & - & - & 0,32 & & - & - & 0,47 & - & - \\
\hline
\end{tabular}

Примечание. *1-й вариант - контроль, обработка семян дистиллированной водой; 2-5-й варианты - продукты переработки растительного сырья и отходов сельскохозяйственного производства, переработанные методом взрывного автогидролиза (ВАГ) (хвоя сосны (ХС), лузга подсолнечника (ЛП), полова овса (ПО), верховой торф (ВТ).

Средние результаты за 2 года испытаний показали широкий диапазон варьирования урожайности по вариантам опыта. Показатель урожайности изменялся от 2,15 т/га на варианте 8 до 2,82 т/га на варианте 5, контроль - 2,60 т/га. Величина урожайности на варианте 5 с исполь- зованием препарата на основе ВТ максимальная в опыте.

Изменчивость признака «урожайность» в благоприятном по погодным условим для культуры 2019 г. была незначительной. Большая стабильность была получена на вариантах 2 (препарат на основе хвои сосны) и 5 (на основе 
верхового торфа), коэффрициент варьирования составил, соответственно, 2,5 и 2,9\%. Варьирование показателей в 2020 г. увеличилось и изменялось по вариантам от 1,9\% (вариант 3, препарат на основе лузги подсолнечника) до 23,3\% (вариант 7, обработка Гумат +7). В среднем за два года исследований вариабельность по вариантам была отмечена от средней $10 \%<\mathrm{Cv}<$ $20 \%$ на вариантах 2-7 до высокой Cv $>20 \%$ варианты 6-10.

Для определения величины доли влияния факторов на изменчивость урожайности был проведён расчёт с использованием двухфакторного анализа (рис. 2). При расчётах было исследовано влияние 2 факторов: год и вариант. Полученные в результате расчётов данные показали, что максимальное влияние (61\%) на фор- мирование урожайности оказывает фрактор «год». Второй по силе влияния - фактор «вариант» - 19\%. Взаимодействие фракторов «сорт $\mathrm{x}$ вариант» оказывает минимальное влияние на признак $-7 \%$.

\section{Заключение}

Результаты исследования показали, что максимально положительное влияние на формирование урожайности ячменя сорта Ворсинский оказывает предпосевная обработка семян препаратами, полученными на основе растительных остатков (лузга подсолнечника, полова овса - варианты 3, 4), отходов деревообработки (хвоя сосны, вариант 2) и верхового торфа (вариант 5) путём их обработки методом взрывного автогидролиза.

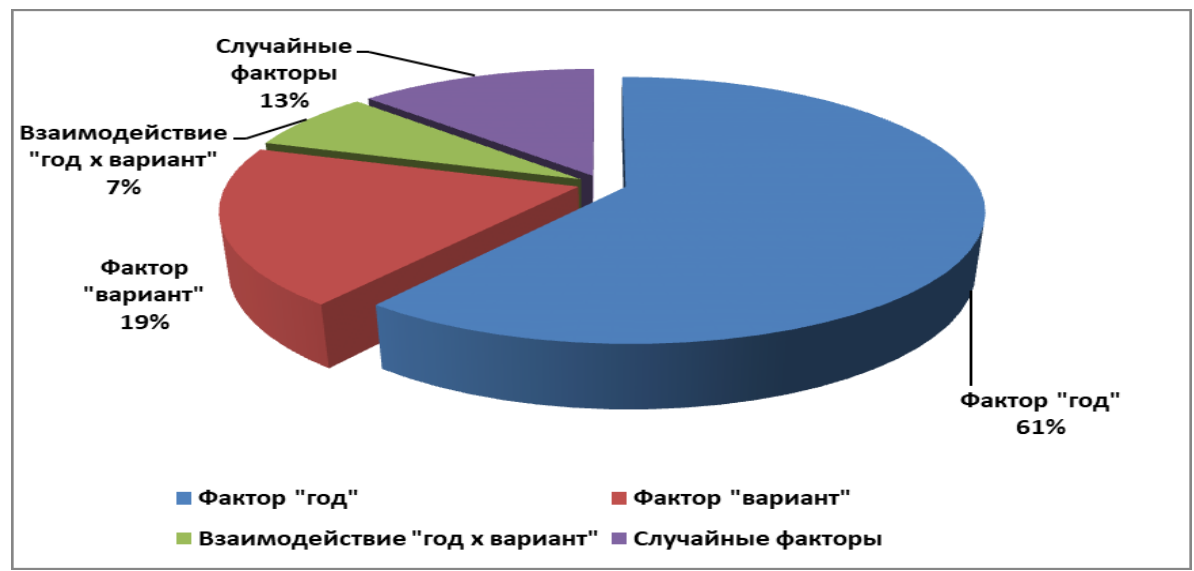

Рис. 2. Результаты двухфакторного диспресионного анализа по признаку "урожайность»

\section{Библиографический список}

1. Zharkova, S., Nechaeva, A., Kiyan, N., Gefke, I. (2020). Producing high-quality seeding material of Russian spring soft wheat varieties in Priobskaya zone of Altay forest steppes. IOP Conference Series: Materials Science and Engineering. 941. $012037 . \quad$ DOI: 10.1088/1757$899 \times / 941 / 1 / 012037$.

2. Указ Президента РФ от 1 декабря 2016 г. N 642 «О Стратегии научно-технологического развития Российской Федерации» (с изменениями и дополнениями). - URL: https://base.garant.ru/71551998 (дата обращения: 20.10.2021). - Текст: электронный.

3. Киян, Н. Г. Изменчивость показателей признаков ячменя ярового в зависимости от сорта и условий выращивания / Н. В. Киян, С. В. Жаркова. - Текст: непосредственный // Международный журнал гуманитарных и естественных наук. - 2019. - № 8-1. - С. 152-155.
4. Площади, сборы и урожайность ячменя в 2001-2019 гг. - URL: https://agro.marimmz.ru/ ploschadi-sbory-urojaynost-yachmenya (дата обращения: 22.10.2021). - Текст: электронный.

5. Жаркова, С. В. Урожайность яровой мягкой пшеницы и её структура в зависимости от обработки семян биологическими препаратами/ С. В. Жаркова, А. В. Нечаева. - Текст: непосредственный // Вестник Алтайского государственного аграрного университета. - 2021. - № 7 (201). - C. 51-56.

6. Методика государственного сортоиспытания сельскохозяйственных культур // Технологическая оценка зерновых, крупяных и зернобобовых культур. - Москва, 1988. - 122 с. - Текст: непосредственный

7. Методические указания по изучению мировой коллекции пшеницы. - Ленинград, 1973. 33 с. - Текст: непосредственный. 


\section{References}

1. Zharkova, S., Nechaeva, A., Kiyan, N., Gefke, I. (2020). Producing high-quality seeding material of Russian spring soft wheat varieties in Priobskaya zone of Altay forest steppes. IOP Conference Series: Materials Science and Engineering. 941. 012037. DOI: 10.1088/1757899X/941/1/012037.

2. Ukaz Prezidenta RF ot 1 dekabria $2016 \mathrm{~g}$. N 642 "O Strategii nauchno-tekhnologicheskogo razvitiia Rossiiskoi Federatsii" (s izmeneniiami i dopolneniiami) [Elektronnyi resurs] URL: https://base.garant.ru/71551998 (data obrashcheniia 20.10.2021).

3. Kiian N.G. Izmenchivost pokazatelei priznakov iachmenia iarovogo $v$ zavisimosti ot sorta i uslovii vyrashchivaniia / N.V. Kiian, S.V. Zharkova // Mezhdunarodnyi zhurnal gumanitarnykh i estestvennykh nauk. - 2019. - No. 8-1. S. 152-155.

4. Ploshchadi, sbory i urozhainost iachmenia $v$ 2001-2019 [Elektronnyi resurs]. URL: https://agro.marimmz.ru/ploschadi-sboryurojaynost-yachmenya (data obrashcheniia 22.10.2021).

5. Zharkova S.V. Urozhainost iarovoi miagkoi pshenitsy i ee struktura $v$ zavisimosti ot obrabotki semian biologicheskimi preparatami / S.V. Zharkova, A.V. Nechaeva // Vestnik Altaiskogo gosudarstvennogo universiteta. - 2021. - No. 7 (201). S. 51-56.

6. Metodika gosudarstvennogo sortoispytaniia selskokhoziaistvennykh kultur // Tekhnologicheskaia otsenka zernovykh, krupianykh i zernobobovykh kultur. - Moskva, 1988 - $122 \mathrm{~s}$.

7. Metodicheskie ukazaniia po izucheniiu mirovoi kollektsii pshenitsy. - Leningrad, 1973. - 33 s.

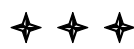

УДК 631/635.25/.26

DOI: 10.53083/1996-4277-2021-206-12-27-33
Т.М. Середин, В.В. Шумилина, С.В. Жаркова

T.M. Seredin, V.V. Shumilina, S.V. Zharkova

\section{НАПРАВЛЕНИЯ И РЕЗУЛЬТАТЫ СЕЛЕКЦИОННОЙ РАБОТЫ ПО ЛУКУ ШАЛОТУ (ALLIUM ASCALONICUM L.) В УСЛОВИЯХ МОСКОВСКОЙ ОБЛАСТИ}

\author{
DIRECTIONS AND RESULTS OF PLANT BREEDING WORK \\ REGARDING SHALLOT (ALLIUM ASCALONICUM L.) \\ UNDER THE CONDITIONS OF THE MOSCOW REGION
}

\begin{abstract}
Ключевые слова: лук шалот, селекция, коллекция, образец, сорт, признак, луковица, высота растения, побег, розетка листьев, урожайность.
\end{abstract}

Луковые культуры и их полезные свойства известны человеку уже многие сотни лет. Биологические особенности луковых культур позволяют использовать их зелёную массу и луковицы в свежем виде практически круглый год. Они хорошо зимуют, отрастают рано весной и используются в то время, когда ещё ни одна культура не дает продукцию из открытого грунта. Один из наиболее распространённых видов луков в настоящее время - это лук шалот (Allium ascalonicum L.). Для успешного введения культуры лука шалота в производственный процесс или для выращивания на приусадебном участке необходимы сорта. В настоящее время в Государственный реестр селекционных достижений, допущенных к использованию, внесено 65 сортов лука шалота. Учитывая, что культура разнообразна по своему морфологическому строению, отзывчивости к условиям вегетации, способности реализовывать свой биологический потенциал, селекционерами ведётся большая работа по отбору перспективного материала и созданию сортов для конкретных регионов возделывания. Целью исследований было изучение коллекционного питомника лука шалота по основным хозяйственно-ценным признакам в условиях Московской области, выделение перспективных форм и создание на их основе новых сортов. Исследование было проведено в 2017-2019 гг. в условиях Московской области на базе ФГБНУ «Федеральный научный центр овощеводства», на опытном участке лаборатории селекции и семеноводства луковых культур. Объекты исследования 80 образцов лука шалота различного экологогеографического происхождения. Реакция сортообразцов в нашем исследовании на условия выращивания значительно различалась. Лук шалот возделывают для получения зелёной массы листьев и луковиц. Из всех сортов, проходящих исследование, 10 по уровню урожайности луковиц достоверно превзошли стандарт сорт Яшма (16,6 т/га). Максимальная урожайность луковиц получена на сорте Золотая звезда - 21,3 т/га, превышение над показателем данного признака у стандарта составило 46,4\%. Полученные в результате 